\title{
13. FAN MARGIN INTRODUCTION AND SUMMARY ${ }^{1}$
}

\author{
Shipboard Scientific Party ${ }^{2}$
}

\section{INTRODUCTION}

Walker and Massingill (1970) identified and mapped two large areas of slump deposits on the Mississippi Fan using $3.5-\mathrm{kHz}$ sub-bottom profiler records. As little information concerning the lithologic characteristics or internal geometry of these deposits existed, a drill site was selected on the easternmost slump mass (Fig. 1). The site would allow an assessment of this slump mass as well as provide additional information on the lateral margins of the most recent and/or underlying fan lobe.

Seismic data in the vicinity of the proposed drill site were sparse. Sub-bottom records showed little or no penetration with the exception of isolated erratic dipping reflectors. In a few instances, these data appear to show multiple sequences, as though several individual massmovement events have occurred. On single channel airgun records, the upper $100 \mathrm{~m}$ consists of a transparent zone capping relatively high amplitude semicontinuous reflectors. Deep-tow $3.5-\mathrm{kHz}$ records acquired approximately $20 \mathrm{~km}$ west of the proposed site, within the slump mass, show chaotic dipping reflectors.

Site 616 was selected to answer three major questions:

1 . Does the transparent zone represent a mass-movement deposit and, if so, what mechanism was responsible for its emplacement?

\footnotetext{
${ }^{1}$ Bouma, A. H., Coleman, J. M., Meyer, A. W., et al., Init. Repts. DSDP, 96: Washington (U.S. Govt. Printing Office).

2 Addresses: Arnold H. Bouma (Co-Chief Scientist), Gulf Research and Development Company, P.O. Box 37048, Houston, TX 77236, (present address: Chevron Oil Field Research Company, P.O. Box 36506, Houston, TX 77236); James M. Coleman (Co-Chief Scientist), Coastal Studies Institute, Louisiana State University, Baton Rouge, LA 70803; Audrey W. Meyer (Shipboard Science Representative), Deep Sea Drilling Project, Scripps Institution of Oceanography, La Jolla, CA 92093, (present address: Ocean Drilling Program, 500 University Drive West, Texas A\&M University, College Station, TX 77843); James Brooks, Department of Oceanography, Texas A\&M University, College Station, TX 77843; William R. Bryant, Department of Oceanography. Texas A\&M University, College Station, TX 77843; Richand Constans, Paleontology Section, Chevron US.A. Inc., 935 Gravier Street, New Orleans, LA 70112: Michel Cremer, Departeme de Otologie et O3s Gravier Street, New Orleans, LA 70112, Michel Cremer, Departe deaux I, Avenue des Facultés, 33405 Talence Cedex, France; Laurence 1. Droz, Laboratoire de Géodynamique Sous-Marine, 06230 Villefranche-sur-Mer, France; Toshio Ishizuka, Ocean Research Institute, University of Tokyo, Tokyo 164, Japan; Mahlon C. Kennicutt II, Department of Oceanography, Texas A\&M University, College Station, TX 77843; Barry Kohl, Chevron U.S.A. Inc., 935 Gravier Street, New Orleans, LA 70112; William R. Normark, Pacific Branch of Marine Geology, U.S. Geological Survey (MS-999), 345 Middlefield Rogd, Menlo Park, CA 94025: Suzanne O'Connell, Lamont-Doherty Geological Observatory of Columbia Drive West, Tis A 1 U Unity Drive West, Texas AdM University, College Station, TX 77843); Mary Parker, Department of Geology, Florida State University, Tallahassee, FL 32306, (present address: AMOCO Production Company, P.O. Box 50879, New Orleans, LA 70150); Kevin T. Pickering, Department of Earth Sciences, University of London, Goldsmith's College, London SE $146 \mathrm{NW}$, United Kingdom; (present address: Department of Geology, University of Leicester, Leicester LE1 7RH, United Kingdom); Claudia Schroeder, Department of Geology, Dalhousie University, Halifax, Nova Scotia B3H 3J5, Canada; Charles E. Stelting, Gulf Research and Development Company, P.O. Box 37048, Houston, TX 77236, (present address: Chevron Oil Field Research Company, P.O. Box 36506, Houston, TX 77236); Dorrik A. V. Stow, University of Edinburgh, Edinburgh EH9 3JW, Scotland, United Kingdom, (present address: Geology Department, University of Nottingham, Nottingham NG7 2RD, United Kingdom); William E. Sweet, Mineral Management Service, P.O. Box 7944, Metairie, LA 77010; Andreas Wetzel, Geologisches Palaeontologisches Institut der Universităt, Sigwartstrasse 10, D7400 Tübingen, Federal Republic of Germany; and Jean K. Whelan, Chemistry Department, Woods Hole Oceanographic Institution, Woods Hole, MA 02543.
}

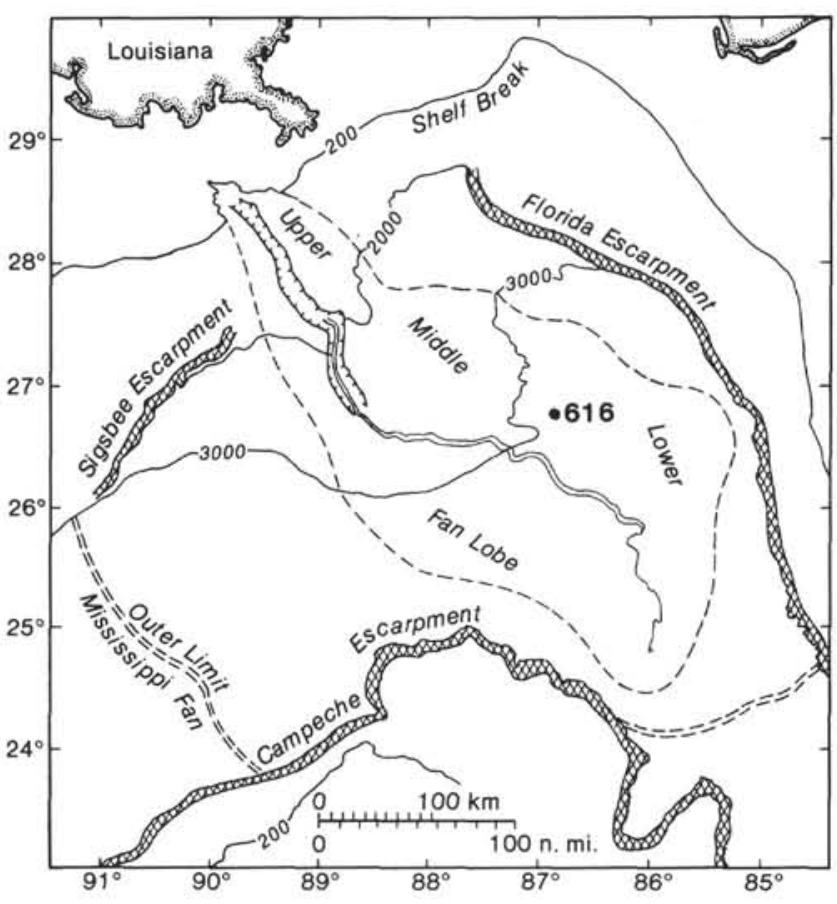

Figure 1. Map of Mississippi Fan with a general outline of the modern fan lobe and the location of Site 616.

2. What are the sedimentologic and geotechnical characteristics of these deposits?

3. Are the semicontinuous reflectors underlying the slump mass the marginal flank deposits associated with the youngest fan lobe or do they represent another fan lobe and, if so, what are their lithologic characteristics?

\section{SUMMARY}

Drilling at Site 616 was considered successful and the major scientific objectives were achieved. The principal results are described next.

1. The upper $96 \mathrm{~m}$ of cored section consists of an overall coarsening-upward fine-grained mud and silty sequence displaying extremely steep dips (ranging up to $65^{\circ}$ ). Numerous small zones of disturbance separate sequences displaying variable dips. The sequence obviously represents emplacement by mass-movement processes, but the source of the sediment is unknown as the entire section was virtually devoid of foraminifers. These observations clearly demonstrate that mass movement with considerable rotation can transport coherent blocks over very low gradients and significant distances.

2. In addition to the mass-movement interval, two fan lobes were cored. The youngest fan lobe is approximately $88 \mathrm{~m}$ thick with a total of $33.8 \mathrm{~m}$ net sand $(38.5 \%)$ and 
is a fining-upward sequence. The lower fan lobe was only partially cored, but appears to display a coarseningupward trend with a minimum of $7 \%$ sand. The sand sequences in the older lobe tend to show graded base sands while in the upper, younger lobe, the sands display both graded and sharp bases. Reexamination of the seismic and shipboard data reveals that these fan lobes predate seismic Horizon " 20 " and thus do not represent marginal deposits belonging to the modern fan lobe in which the other sites were drilled.

3. The entire section contains sparse planktonic foraminifers, indicating a rapid sedimentation rate. One interval, from 65 to $150 \mathrm{~m}$ sub-bottom, contains a relatively high faunal content, possibly representing slower sedimentation rates. Ericson's Zone Z (Holocene) was less than $1 \mathrm{~m}$ thick; most of the cored section was deposited during Ericson's Zone Y (late Wisconsin glacial). Based on seismic correlations of Zone X, the sedimentation rate may be as high as $5.5 \mathrm{~m} / 1000$ yr. The site clearly demonstrates that thick series of fine-grained sediments can be deposited rapidly in deep-water settings and that low or nondepositional periods are too short to accumulate planktonic foraminifers.

\section{REFERENCE}

Walker, J. R., and Massingill, J. V., 1970. Slump features on the Mississippi Fan, northeastern Gulf of Mexico. Geol. Soc. Am. Bull., 81:3101-3108. 